\section{DETERMINISANjE FAKTORA PUT KAO UTICAJNOG FAKTORA NA SAOBRAĆAJNE NEZGODE PRIMENOM DUBINSKIH ANALIZA}

Nenad Marković, dipl. inž. saobraćaja

Univerzitet u Beogradu, Saobraćajni fakultet, n.markovic@sf.bg.ac.rs

Prof. dr Dalibor Pešić, dipl. inž. saobraćaja

Univerzitet u Beogradu, Saobraćajni fakultet, d.pesic@sf.bg.ac.rs

Prof. dr Boris Antić, dipl. inž. saobraćaja

Univerzitet u Beogradu, Saobraćajni fakultet, b.antic@sf.bg.ac.rs

Prof. dr Krsto Lipovac, dipl. inž. saobraćaja

Univerzitet u Beogradu, Saobraćajni fakultet, k.lipovac@gmail.com

Miljan Lazarević, dipl. inž. saobraćaja

Univerzitet u Beogradu, Saobraćajni fakultet, miljanlazarevic2@gmail.com

\section{DOI: 10.31075/PIS.64.02.07}

Стручни рад

Rezime: Osnov za kvalitetno preventivno delovanje u sprečavanju nastanka saobraćajnih nezgoda je kvalitetno sagledavanje uticajnih faktora na nastanak saobraćajnih nezgoda i posledica. Kao najsveobuhvatniji metod za utvrđivanje uticajnih faktora na saobraćajne nezgode, u svetu su razvijeni različiti modeli dubinskih analiza saobraćajnih nezgoda. Primenom metodologije dubinskih analiza na konkretnu saobraćajnu nezgodu detaljno se utvrđuje uticaj puta, vozila, čoveka i okruženja na tu saobraćajnu nezgodu. Ova metodologija posebno omogućava detaljno analiziranje uticaja puta na nastanak i posledice analizirane nezgode, što upravljačima puta omogućava kvalitetno prepoznavanje konkretnih nedostataka puta, na tom mestu. Praćenjem prepoznatih nedostataka puta (uticaja faktora put) na konkretnim lokacijama mogu se prepoznati potencijalno opasna mesta, sa sličnim karakteristikama, na celoj mreži što omogućava planiranje preventivnog delovanja od strane upravljača puta. $U$ R.Srbiji, na teritoriji grada Beograda, sprovedene su dubinske analize saobraćajnih nezgoda, u periodu od jedne godine $i$ prepoznati su određeni uticaji puta na nastale saobraćajne nezgode, o čemu će biti detaljnije objašnjeno u ovom radu.

Ključne reči / Keywords: saobraćajna nezgoda, uticaj faktora put, dubinska analiza, nastanak i posledice nezgoda.

\section{DETERMINATION OF INFLUENTIAL ROAD FACTORS IN ROAD ACCIDENTS USING IN- DEAPTH ANALYSIS}

Nenad Marković, M.Sc. T.E.

University of Belgrade - Faculty of Transport and Traffic Engineering, n.markovic@sf.bg.ac.rs

Dalibor Pešić, Ph.D. T.E.

University of Belgrade - Faculty of Transport and Traffic Engineering, d.pesic@sf.bg.ac.rs
Boris Antić, Ph.D. T.E.

University of Belgrade - Faculty of Transport and Traffic Engineering, b.antic@sf.bg.ac.rs

Krsto Lipovac, Ph.D. T.E.

University of Belgrade - Faculty of Transport and Traffic Engineering, k.lipovac@gmail.com

Miljan Lazarević, , B.Sc. T.E.

University of Belgrade - Faculty of Transport and Traffic Engineering, miljanlazarevic2@gmail.com

Professional paper

Abstract: The basis of traffic accidents prevention requires a good understanding of the impact of external factors and consequences of traffic accidents. As the most comprehensive method for determining the impact factors of traffic collisions developed various models of in-depth analysis of traffic accidents. Applying methodology of in-depth analysis of a certain traffic accident, we can understand the influence of the road, the vehicles, the human, and the environment on the certain traffic accident. This method allows us to understand the influence of the road. According that road safety managers of roads can observed insight into the specifics of the road in terms of road safety. By identifying road defects at specific locations, we can recognize the potentially dangerous locations that have similar characteristics. That allows the road safety managers of roads the planning of preventive actions. In the Republic of Serbia, more specifically, in the territory of the city of Belgrade, in-depth analyses of traffic accidents have been conducted over a period of one year. Applying in-depth analysis defined certain characteristics of the road have been shown to lead to the occurrence of a traffic accident. In this paper, we will examine certain characteristics of the road.

Ključne reči / Keywords: traffic accident, influential factors, in-depth analysis, consequences.

\section{UVOD}

U svetu je u poslednje vreme zabeležen trend permanentnog povećanja broja i posledica saobraćajnih nezgoda, na globalnom nivou. Prema podacima (WHO, 2013), tokom 2010. godine broj smrtnog stradanja u saobraćajnim nezgodama je dostigao broj od 1,23 miliona poginulih. Prema raspoloživim podacima i uočenim trendovima prisutna je tendencija daljeg povećanja broja stradalih u saobraćaju. Prema tim podacima procenjuje se da bi prema datom trendu 2030. smrtno stradanje u saobraćaju postao peti uzrok smrtnosti u svetu. Među štetnim posledica u društvu, saobraćajne nezgode se izdvajaju kao najčešća nasilna smrt, a pogotovo kod mladih (starosti od 15 do 29 godina), gde su saobraćajne nezgode prvi uzrok smrtnosti (WHO, 2013). Osim smrtnog stradanja ljudi u saobraćajnim nezgodama, nastaju i velike materijalne štete i druge posledice, a što sve 
zajedno stvara izuzetno velike socijalne troškove. Procenjuje se da jedna saobraćajna nezgoda $u$ zavisnosti od nastalih posledica može predstavljati trošak od najmanje $3.082,00$ eura (nezgoda sa lako povređenim) do 309.753,00 eura, (Antic et all., 2012) pa do čak 2.299.016,00 eura (Ministarstvo transporta Velike Britanije, 2013).

Imajući u vidu uočene trendove stradanja u saobraćaju Generalna Skupština Ujedinjenih nacija je 10. maja 2010. godine donela Rezoluciju 64/255 „Unapređenje bezbednosti saobraćaja na putevima" sa ciljem zaustavljanja postojećeg trenda i uspostavljanja trenda smanjenja broja stradanja u saobraćaju. $U$ ovoj rezoluciji su date smernice za preventivni rad u bezbednosti saobraćaja i proglašen je period 20112020 godina dekadom za bezbednost saobraćaja na putevima, čiji je osnovni cilj da se smanji broj poginulih za $50 \%$ do 2020. godine. Kao posledica preduzetih mera u mnogim zemljama je započeto uspostavljanje sistemskog preventivnog delovanja u cilju smanjenje broja saobraćajnih nezgoda. Za sistemsko delovanje neophodno je prevashodno na kvalitetan način analizirati trenutno stanje i analizirati saobraćajne nezgode u cilju prepoznavanja i definisanja faktora koji su imali uticaj na nastanak i posledice saobraćajnih nezgoda. Utvrđivanje uticajnih faktora i adekvatnog prepoznavanja njihovog uticaja nije jednostavan postupak, pa se iz tog razloga veoma često pojedini od uticajnih faktora zanemare ili previde. Nedovoljno sagledavanje uticaja pojedinih faktora može za posledicu imati prenaglašavanje uticaja pojedinih prepoznatih faktora, a sa druge strane neprepoznavanje velikog broja stvarnih uticaja. Tek po kvalitetnom sagledavanju svih uticaja na nastanak i posledice saobraćajne nezgode moguće je pripremiti plan mera i aktivnosti usmerenih ka smanjenju broja saobraćajnih nezgoda i njihovih posledica.

Kvalitetno sagledavanje velikog broja potencijalnih uticaja svakog od faktora je izuzetno složeno i zahteva razvijanje složenih modela, na osnovu kojih bi se sistematizovali prikupljeni podaci o uticaju svakog pojedinačnog faktora. Ovo zahteva razvoj i formiranje baze podataka o uticajnim faktorima, saobraćajnih nezgoda, a čemu je neophodno da predstoji razvoj modela prikupljanja podataka o uticajnim faktorima. Razvijeni model za prikupljanje podataka mora na sistematičan način da sagleda i prikuplja podatke o saobraćajnoj nezgodi i detaljno analizira uticaje svakog od faktora (Čovek-VoziloPut-Okruženje). Ovaj proces bi, imajući u vidu da na saobraćajnu nezgodu može imati uticaja više hiljada različitih faktora, kao i da više faktora istovremeno ili u sadejstvu mogu uticati, bio izuzetno složen, pa ga je neophodno postepeno razvijati i definisati set osnovnih uticajnih faktora koji će na dovoljno kvalitetan i pouzdan način definisati stvarne uticaje na nastalu nezgodu.

\section{DEFINISANJE UTICAJNIH FAKTORA}

Za definisanje uticajnih faktora na nastanak saobraćajnih nezgoda najčešće se u praksi koriste raspoloživi podaci koje policija prilikom vršenja uviđaja prikuplja. Ovi podaci su najčešće osnovni podaci o saobraćajnoj nezgodi i okolnostima koje su u neposrednoj vezi sa nastalom nezgodom. Obim podataka koje prikuplja policija prilikom vršenja uviđaja saobraćajne nezgode, najčešće omogućava samo sprovođenje fenomenološke analize saobraćajne nezgode. Ovakve analize saobraćajnih nezgoda mogu da definišu globalne probleme bezbednosti saobraćaja i ukažu eventualno na uočene probleme, jer u njihovoj analizi figurišu zbirni podaci o saobraćajnim nezgodama. $\mathrm{Na}$ ovaj način dolazi se do zaključaka gde i kada se najčešće događaju saobraćajne nezgode, koje su kategorije učesnika saobraćajnih nezgoda, kakve posledice nastaju, koji su bili propusti učesnika itd. Kao što se može videti ove analize ne daju dovoljno pouzdane podatke o uzrocima i okolnostima nastanka saobraćajnih nezgoda, a što je osnov za kvalitetno preventivno delovanje u cilju sprečavanja nastajanja budućih nezgoda.

Osim analiza na osnovu podataka prikupljenih sa mesta nezgode, u poznatoj praksi, često se za potrebe sudskog procesa, vrše saobraćajno-tehnička veštačenja, gde se na osnovu do tada prikupljenih podataka (od strane policije, svedoka, učesnika nezgode i sl.) utvrđuju uzrok i okolnosti nastanka te saobraćajne nezgode. Najčešće ove analize su ograničene količinom i kvalitetom prikupljenih podataka u sudskom procesu i neretko ne daju dovoljno dobre rezultate pri utvrđivanju svih uticajnih faktora. Naime, za sudski proces je interesantno dokazivanje uticaja pojedinih faktora, dok se ostali faktori mogu i zanemariti ili se pak ne obraća posebna pažnja na njih, u zavisnosti od optužnice. Ova vrsta analize za razliku od fenomenološke daje mnogo veći nivo detaljnosti i predstavlja jednu vrstu etioloških analiza saobraćajnih nezgoda. Etiološke analize se fokusiraju na konkretnoj nezgodi i detaljnije proučavaju svaku pojedinačnu nezgodu i omogućavaju da se utvrde stvarni uzroci i okolnosti nastanka saobraćajnih nezgoda, kao i potencijalni uticaji na posledice. Etiološkim analizama se prepoznaju i definišu uticajni faktori za svaku saobraćajnu nezgodu, što omogućava praćenje i analizu učestalosti pojave uticaja pojedinih faktora, a što može ukazivati na postojanje značajne zavisnosti uticaja prepoznatog faktora na saobraćajne nezgode. Kao jedan od modela izuzetno kavlitetnih etioloških analiza saobraćajnih nezgoda se izdvojio model dubinskih analiza saobraćajnih nezgoda, koji osim detaljnog analiziranja raspoloživih podataka (prikupljenih na mestu nezgode), omogućava i dodatne analize od strane istraživača, što na terenu (mestu nezgode), što kasnije kroz analizu stanja vozila, ili stavova učesnika nezgode. 
Još davne 1980. godine Haddon je sistematizovao uticajne faktore na četiri osnovne grupe faktora i to grupu čovek, vozilo, put i okruženje. Ovakvom podelom uticajnih faktora ukazano je da se uzroci i okolnosti nastanka saobraćajnih nezgoda moraju tražiti u svakom od navedenih faktora, a što nije svojstveno fenomenološkim analizama, kao ni saobraćajno-tehničkim veštačenjima, jer se ona bave pojedinim uticajima. Do sada je u praksi najčešće uticaj faktora čovek bio dominantno prepoznavan, kao uzročnih saobraćajnih nezgoda, pri čemu nije detaljno analiziran $i$ istraživan, što zbog zahtevnosti takvog istraživanja, kao i zbog zaštite podataka o ličnosti i neophodnog ličnog pristanka ispitanika. U praksi je jedan od većih problema spremnost učesnika nezgode da daju iskrene i tačne odgovore, bojeći se eventualnih sankcija. Sa daljim razvojem analiza soabraćajnih nezgoda uočeno je da ne tako često osim vozača sa njim u sadejstvu ili samostalno i vozilo, i put i okruženje imaju uticaja na nastanak nezgoda.

Prema podacima PIARC-a (2011) faktor čovek samostalno utiče sa $57 \%$ na nastanak saobraćajnih nezgoda, dok u sadejstvu sa ostalim faktorima taj uticaj doseže $93 \%$, što svakako predstavlja dominantan uticaj ovog faktora u odnosu na ostale faktore. S druge strane i ostali faktori imaju značajan uticaj, tako da faktor put zajedno sa ostalim faktorima utiče sa $44 \%$, a vozilo sa $13 \%$ na nastanak saobraćajnih nezgoda. Kada se analiziraju pojedinačni uticaji posebno se značajnom analizom može smatrati analiza uticaja faktora put na nastanak saobraćajnih nezgoda i posledica. Posebno je važno naglasiti da faktor put često može imati uticaj na izbegavanje ili smanjenje posledica $u$ saobraćajnim nezgodama koje se ne mogu izbeći. Naime, kako je put pasivni učesnik saobraćajne nezgode, njegov uticaj je gotovo uvek prisutan bez obzira na ostale učesnike, kao i na činjenicu da li će se nezgoda dogoditi usled uticaja puta ili ne. S druge strane put bi kao deo saobraćajne infrastrukture morao da doprinosi povećanju bezbednosti saobraćaja, a ne da bude jedan od uzročnika nastanka saobraćajnih nezgoda, pa je i iz tog razloga neophodno kvalitetno sagledati njegov uticaj. Prema podacima PIARC-a faktor put kao samostalni uzročnik nastanka saobraćajnih nezgoda je prepoznat u $13 \%$ nezgoda, u $26 \%$ u sadejstvu sa uticajem faktora čovek, $1 \%$ u sadejstvu sa faktorom vozilo, dok je u $4 \%$ u sadejstvu sva tri faktora.

Prema dostupnim podacima u Republici Srbiji ukupan uticaj ostalih faktora izuzev faktora čovek je prepoznat u manje od $1 \%$ saobraćajnih nezgoda, dok je uticaj faktora čovek u preko $99 \%$ saobraćajnih nezgoda. Imajući to u vidu ukupan uticaj faktora put na nastanak saobraćajnih nezgoda u Republici Srbiji je znatno manji od $1 \%(0,07 \%)$, dok je u Svetu oko $44 \%$. Ovo jasno ukazuje na činjenicu da se u Republici Srbiji ne utvrđuju dovoljno uticaji ostalih faktora, osim faktora čovek na nastanak saobraćajnih nezgoda i posledica. Imajući u vidu stanje saobraćajne infrastrukture u razvijenim zemljama Sveta i Republici Srbiji, uočena je potreba za detaljnijom analizom saobraćajnih nezgoda i realnim utvrđivanjem uticaja svakog od faktora, a posebno uticaja faktora put na nastanak saobraćajnih nezgoda i posledica.

U Evropi je za utvrđivanje uzroka i okolnosti saobraćajnih nezgoda razvijen i usvojen program dubinskih analiza saobraćajnih nezgoda od strane European Reintegration Support Organisations (ERSO), koji je detaljno razrađen u okviru poglavlja 5 projekta SafetyNet (Bjorkman et al., 2008). U Australiji je još 2003. godine sprovedena prva Australijska nacionalna dubinska analiza saobraćajnih nezgoda u kojoj su analizirane saobraćajne nezgode iz dve države (Vikotrija i Novi južni Vels) za period 2000-2003. (Fildes et al. 2003). U Velikoj Britaniji je sprovedeno više dubinskih analiza različitih kategorija učesnika u saobraćaju, pod nazivom "On-The-Spot accident research" (Hill and Cuerden 2015). Univerzitet u Adelaidi je 1975. godine započeo primenu dubinskih analiza saobraćajnih nezgoda, što u nastavku i dalje razvija kroz veći broj sprovedenih dubinskih analiza saobraćajnih nezgoda (Baldock et al. 2008). U okviru SUPREME projekta Evropske komisije jedna od celina bila je i izveštaj dubinskih analiza saobraćajnih nezgoda (Europea Commission 2010).

Zadatak dubinskih analiza saobraćajnih nezgoda je prepoznavanje i utvrđivanje faktora koji su uzrokovali nastanak saobraćajne nezgode, kao i ostalih faktora od uticaja na posledice saobraćajne nezgode. U radu je Pešić sa grupom autora (2014) dao pregled najbolje Svetske prakse u vršenju dubinskih analiza saobraćajnih nezgoda, kao i prikaz nekih od metodologija vršenja dubinskih analiza. U okviru projekta SafetyNet definisan je veliki broj varijabli koje je neophodno prikupiti u vezi sa nezgodom, a po principu istraživanja poznatog kao SafetyNet Accident Causation System (SNACS) (Reed and Morris, 2008). Po broju definisanih uticajnih faktora najdalje su otišli u Nemačkoj, gde je u okviru baze podataka o dubinskim analizama GIDAS definisano više hiljada uticajnih faktora. Imajući u vidu veliki broj definisanih i prepoznatih uticajnih faktora, sprovođenje ovakvih analiza iziskuje velike vremenske i materijalne troškove, pa se ove analize u praksi retko sprovode ili se sprovode na određenom ograničenom području (jednog grada), za ograničeni vremenski period. Kako bi se prevazišao ovaj ograničavajući faktor široj primeni dubinskih analiza u praksi pojedini autori su vršili dubinske analize posmatrajući samo pojedine uticajne faktora, kao na primer Penumaka i ostali (2014) koji su ispitivali isključivo uticaj faktora čovek na nastanak saobraćajne nezgode. 
Složenost i specifičnost uticajnih faktora na nastanak saobraćajne nezgode su dokazali i Odenheimer i ostali (1994), koji su u svom radu napravili iskorak definišući indekse za uticaj puta na nastanak saobraćajne nezgode. Navedeni autori su ispitali i utvrdili pouzdanost faktora puta na nastanak saobraćajne nezgode na uzorku od 30 konkretnih studija slučajeva saobraćajnih nezgoda. U svom radu su Marković i ostali (2015) posebno ukazali na značaj vršenja dubinskih analiza za pravilno utvrđivanje i definisanje uticaja puta na nastanak $i$ posledice saobraćajnih nezgoda. Gitelman I ostali. (2012) su između ostalog analizirali karakteristike lokacije saobraćajnih nezgoda sa pešacima i dovodili in u vezu sa karakteristikama učesnika nezgoda.

Jedan od modela dubinskih analiza na javnim putevima je datu radu čiji su autori Markovic i ostali. (2015b). Sprovođenje ovakvog prikupljanja podataka bi zahtevalo duži vremenski period, kako bi se prikupio dovoljno veliki i reprezentativan uzorak uticajnih faktora, na osnovu koga bi bilo moguće utvrditi stvarne uticaje. Imajući to u vidu razvijena je metodologija praćenja i prikupljanja uticaja pojedinih faktora nekom trenutno primenljivijom metodologijom, pa su ekspertize saobraćajnih nezgoda prepoznate kao izuzetan izvor uticajnih faktora na nastanak i posledice saobraćajnih nezgoda. Prikupljanjem uticajnih faktora na osnovu ekspertiza saobraćajnih nezgoda mogu se dobiti osnovni uticajni faktori na nastanak i posledice saobraćajnih nezgoda, a u skladu sa metodologijom i rezultatima ekspertiza saobraćajnih nezgoda. Ovako dobijen set osnovnih faktora se svakako može dalje unapređivati, usavršavati i korigovati sa prepoznavanjem uticajnih faktora utvrđenih sprovedenim dubinskim analizama, na koji način će biti verifikovani najuticajniji faktori u vezi saobraćajnih nezgoda. Prema rezultatima sprovođenja dubinskih analiza saobraćajnih nezgoda sa poginulim licima na teritoriji grada Beograda utvrđen je uticaj puta kao uzroka nastanka saobraćajnih nezgoda sa $3,37 \%$, dok je uticaj puta na nastanak saobraćajnih nezgoda prepoznat u $28,1 \%$ saobraćajnih nezgoda.

\section{DETERMINACIJA FAKTORA PUT NA SAOBRAĆAJNE NEZGODE}

Analiza uticaja faktora put je od izuzetnog značaja za preventivno delovanje u bezbednosti saobraćaja, jer je njegov uticaj uvek prisutan, pa makar i ne bio prepoznat za konkretnu nezgodu. Uticaj puta $u$ nekim slučajevima može biti u uzročnoj vezi sa nastankom ili mogućnošću izbegavanja saobraćajne nezgode, ali u većini slučajeva uticaj faktora put je u vezi sa težinom posledica ili mogućnošću umanjenja posledica saobraćajne nezgode.
Ono što je važno istaći je da faktor put, odnosno određene njegove karakteristike ne dovode uvek do nastanka saobraćajnih nezgoda, već u određenim uslovima odvijanja saobraćaja i drugim okolnostima mogu dovesti do destabilizacije vozila i nastanka nezgode. S druge strane određene karakteristike faktora put dolaze do izražaja samo u određenim saobraćajnim nezgodama jer utiču na uvećanje posledica te nezgode, zbog specifičnosti baš te konkretne nezgode. Imajući to u vidu neophodno je prepoznati te specifične uticaje faktora put na nastale saobraćajne nezgode, kako bi se uticalo na izbegavanje nastanka i smanjivanje posledica saobraćajnih nezgoda, odnosno kako bi se preventivno delovalo u cilju smanjenja negativnih posledica saobraćaja.

Analizom baze podataka dubinskih analiza soabraćajnih nezgoda na teritoriji grada Beograda u periodu od 14.01.2016. godine do 14.01.2017. godine u $3,37 \%$ saobraćajnih nezgoda sa poginulim licima je prepoznat uticaj faktora put kao uzročnika nastanka saobraćajne nezgode. $U$ analiziranom uzorku nezgoda kao osnovni uticaj faktora put na nastanak nezgode se izdvojio nedostatak u vezi sa saobraćajnom signalizacijom, i to neodgovarajuća/ nepostojeća ili nedovoljno uočljiva saobraćajna signalizacija, za čime sledi uticaj privremene saobraćajne signalizacije u zoni radova. Takođe je na istom uzorku saobraćajnih nezgoda utvrđeno da je uticaj faktora put prepoznat u još $28,1 \%$ saobraćajnih nezgoda sa poginulim licima, što ukupno čini $31,47 \%$ prepoznatog uticaja faktora put na nastanak saobraćajnih nezgoda sa smrtnim posledicama.

\subsection{Uticaj faktora put na nastanak saobraćajne nezgode}

Kada je reč o uticaju na nastanak saobraćajne nezgode faktor put utiče najčešće kroz nekoliko vrsta uticaja. Naime, osnovni način uticaja je u pogledu stvaranja neregularne saobraćajne situacije izostankom pružanja adekvatne informacije jednom od učesnika ili svim učesnicima u saobraćaju. S druge strane postavljena saobraćajna signalizacija može pružati različite (suprotne) informacije različitim učesnicima u saobraćaju što in može dovesti $u$ potencijalni konflikt. Takođe, saobraćajna signalizacija postavljena tako da ne omogućava blagovremeno prilagođavanje načina vožnje vozača, može dovesti do stvaranja opasnih situaicja u saobraćaju. U posmatranom uzorku nezgoda oko 4\% nezgoda se dogodilo, pri čemu je glavni uticajni faktor bio u vezi sa neadekvatno postavljenom saobraćajnom signalizacijom ili nepostojanjem saobraćajne signalizacije. U $12 \%$ slučajeva nepostojanje saobraćajne signalizacije ili neadekvatno postavljena saobraćajna signalizacija je bila ostali utcajni faktor na nastanak saobraćajne nezgode. 
Osim regulisanjem saobraćaja faktor put može i svojom geometrijom odnosno tehničko eksploatacionim svojstvima da dovede do nastanka saobraćajne nezgode. Naime, faktor put kroz nepružanje bezbednih tehničko eksploatacionih uslova za određeni nivo saobraćajnice (stanje površine kolovoza, pružanje puta i sl.) može takođe uzrokovati nastanak nezgode.

\subsubsection{Neadekvatno vođenje saobraćajnih tokova}

$\mathrm{Na}$ osnovu izvršenih analiza uočeno je da je na određeni broj saobraćajnih nezgoda imalo uticaja nastanak neadekvatnog označavanja i vođenje saobraćajnih tokova. Naime, nepostojanje ograničenja brzine u skladu sa geometrijskim karakteristikama puta (53\% nezgoda se dogodilo na putu gde je ograničenje brzine do $50 \mathrm{~km} / \mathrm{h}$, a $36 \%$ negoda na putu gde je ograničenje brzine do 80 $\mathrm{km} / \mathrm{h}$ ), izostanak najave oštrih krivina, neobeležavanje krivina, posebno nakon dužih pravaca, često dovode vozače u situaciju da intenzivno reaguju kako bi prilagodili dotadašnji način kretanja vozila delu puta na koji nailaze, a za šta nisu blagovremeno upozoreni. Nekada, intenzivno reagovanje vozača za psledicu ima promenu načina kretanja vozila $\mathrm{i}$ prilagođavanje potrebnih tehničkim uslovima, ali u određenom broju situacija i tako preduzeto reagovanje ne omogućava bezbedan prolaz predstojećim delom puta, što za posledicu ima nastanak nezgode. Kao što je već rečeno nije redak slučaj da na delu puta koji se nalazi u pravcu a kome predstoji oštra krivina nema signalizacije koja bi blagovremeno upozorila vozače da nailaze na oštru krivinu i da ne mogu bezbedno proći brzinom koja je tu ograničena. Upravljači puta se često pozivaju na činjenicu da su vozači dužni da prilagode način vožnje uslovima u saobraćaju, međutim ukoliko vozači nemaju informaciju o tome, oni nemaju razloga da očekuju promenu načina kretanja. Shodno tome upravljači puta su dužni da blagovremeno i na propisani način obeleže svaku promenu u uslovima odvijanja soabraćaja, a koja bi mogla da bude iznenađujuća za vozače.

$U$ analiziranom uzorku saobraćajnih nezgoda bilo je nezgoda gde vozaču nije bilo ni na koji način signalisano da nailazi na oštru krivinu, nakon dužeg pravca, niti je krivina bila na bilo koji način obeležena, kako bi vozač imao mogućnosti da u noćnim uslovima vožnje ranije uoči da nailazi na krivinu. Na delu puta ispred mesta nezgode brzina nije bila posebno ograničena već je važilo opšte ograničenje brzine do $80 \mathrm{~km} / \mathrm{h}$, kao i u krivini. Vozilo je pri prolasku kroz krivinu, izgubilo upravljivost i došlo je do destabilizacije vozila i silaska sa kolovoza i udara u ogradu na unutrašnjoj strani krivine. Naime, zbog neblagovremnog najavljivanja krivine od strane upravljača puta, vozač je u krivinu ušao brzinom većom od bezbedne, što je za posledicu imalo destabilizaciju vozila, nakon čega vozač u cilju korigovanja putanje kretanja preduzima dodatno skretanje što za posledicu ima silazak vozila sa kolovoza i nastanak nezgode.

Neblagovremeno obaveštavanje učesnika u saobraćaju na predstojeće promene u saobraćajnom toku su takođe imale uticaja na nastanak analiziranih saobraćajnih nezgoda. $U$ jednoj saobraćajnoj nezgodi, kao i u pethodnom slučaju nakad duže deonice u pravcu, nakon blage krivine se izvode radovi na kolovozu, pri čemu je jedna od saobraćajnih traka zatvorena za saobraćaj. Ipsred mesta nezgode je ograničenje brzine do $80 \mathrm{~km} / \mathrm{h}$, i nema blagovremeno najavljenih radova na putu. Nakon izlaska iz krivine, kada su se stekli uslovi vozač uočava obeležene radove na putu, ali koji ranije nisu bili signalisani, i preduzima intenzivno kočenje zbog vozila koja se nalaze u zoni radova. Drugo vozilo koje ga sledi nema tehničkih mogućnosti da blagovremeno uoči radove na putu i kada uočava da se teretno vozilo ispred njega zaustavlja preduzima takođe forsirano kočenje. Zbog nemogućnosti ranijeg uočavanja zone radova i ranijeg preduzimanja usporavanja, dolazi do sustizanja pomenuta dva vozila nakon čega dolazi i do sudara sa vozilom iz suprotnog smera. Zbog izostanka blagovremenog najavljivanja zone radova, oba vozača su dovedena u opasnu situaciju, gde su prinuđeni da preduzimaju forsirano kočenje u cilju izbegavanja opasnosti, a što in je sprečilo u izbegavanju ove nezgode.

Kada je reč o vođenju saobraćajnih tokova značajan uticaj na nastanak saobraćajnih nezgoda sa ranjivim učesnicima u saobraćaju ima nedostatak, ili neuređenost površina namenjenih za kretanje ranjivih učesnika u saobraćaju. U $8 \%$ nezgoda nepostojanje uređenih površina za kretanje ranjivih učesnika u saobraćaju je bilo uticajni factor koji je doprineo nastanku saobraćajne nezgode. Naime, nedostatak trotoara na prolascima državnih puteva kroz naselja je jedan od čestih razloga kretanja pešaka po kolovozu, a što može biti iznenađujuće za vozače posebno prilikom stuapanja pešaka na kolovoz ili pri promeni pravca kretanja pešaka na kolovozu. Takođe još izraženiji problem je nedostatak staza za bicikle, posebno u delovima gde se bicikl u znatnoj meri koristi kao prevozno sredstvo, jer su vozači bicikala i ostali vozači primorani da koriste istu površinu za kretanje što in često dovodi u konflikt.

\subsubsection{Nedosledno regulisanje prvenstva prolaza}

Oboreni saobraćajni znak kojim se reguliše prvenstvo prolaza na raskrsnici na kojoj se dogodila nezgoda, a koji je bio oboren duže vreme pre nastanka nezgode, i koji nije zamenjen ispravnim 
saobraćajnim znakom, jer za posledicu imao dovođenje u zabludu dva vozača u vezi činjenice ko je imao prvenstvo prolaza na predmetnoj raskrsnici. Naime, vozač koji je prošao pored oborenog saobraćajnog znaka, nije imao obaveštenje da nailazi na put sa prvenstvom prolaza, a drugom učesniku u saobraćaju je dolazio sa desne strane, pa je prema pravilima saobraćaja mogao imati prvenstvo u prolazu. S druge strane drugom učesniku u saobraćaju je jasno saobraćajnim znakom saopšteno da se kreće putem sa prvenstvom prolaza. Na ovaj način su oba vozača dovedena u zabludu o stvarnom prvenstvu prolaza na predmetnoj raskrsnici, što je za posledicu imalo nastanak saobraćajne nezgode sa poginulim licem.

\subsubsection{Geometrija kolovoza}

Promena geometrije puta, koja nije signalisana, je takođe često uzrok nastanka soabraćajnih nezgoda, jer iznenadna promena geometrije sa sobom nosi i značajno dugačije uslove za bezbedan prolazak, što može iznenaditi učesnike u saobraćaju u vezi neophodnog načina vožnje. Posebno opasan se izdvaja pelazak geometrije puta sa boljim performansama na deo puta sa značajno lošijim performansama, što ne omogućava vozačima da prethodnim načinom vožnje bezbedno prođu kroz predstojeću deonicu. U praksi je čest slučaj da se u dugačkim i blagim krivinama vrši promena radijusa krivina unutar jedne krivine, što značajno menja uslove za bezbedan prolazak kroz takvu krivinu. Naime, vozač prilikom ulaska u krivinu sagleda karakteristike krivine i prilagodi način kretanja toj krivini, a prilikom prolaska kroz krivinu, uočava da se ti uslovi pogoršavaju i da je neophodno da kroiguje način vožnje, što u uslovima prolaska kroz krivinu može za posledicu imati destabilizaciju i nastanak saobraćajne nezgode.

Poromena poprečnog nagiba kolovoza može za posledicu imati stvaranje opasnih deonica na putu, koje iz više razloga mogu iznenaditi učesnike u saobraćaju. Ove promene poprečnog nagiba su izuzetno opasne u uslovima smanjenog prianjanja kolovoza, jer je tada dominantan uticaj poprečnog zadržavanja vozila. Naime, nepravilan poprečni nagib kolovoza u krivini znatno smanjuje bezbednu brzinu za prolazak kroz predmetnu krivinu, što može iznenaditi vozače ukoliko o tome nisu blagovremeno obavešteni. S druge strane promena poprečnog nagiba značajno menja i granične vrednosti parametara za bezbedan prolazak kroz krivinu, što je od presudnog značaja za gubljenje stabilnosti i upravljivisti vozilom. Promena poprečnog nagiba kolovoza, takođe ima uticaja i na odvodnjavanje površine kolovoza. Naime, nagib površine kolovoza usmerava površinsku vodu sa kolovoza niz poprečni nagib, što pri promeni poprečnog nagiba dovodi $u$ situaciju da se voda može naći ili zadržati na kolovozu, na delu na kome se menja poprečni nagib, posebno ako nema izraženog poprečnog nagiba. Ovakva situacija može dovesti do smanjenja prianjanja kolovoza i do pojave efekta "akvaplaninga", gde usled postojanja sloja vode na kolovozu dolazi do gubitka prianjanja sa pneumatikom vozila, što svakako za posledicu ima gubitak upravljivosti vozila. Ovakva promena uslova prianjanja direktno utiče na graničnu brzinu za bezbedan prolazak, što za vozača predstavlja iznenadnu promenu na koju on instiktivno reaguje $i$ često dodatno destabilizuje vozilo. U posmatranom uzorku $69 \%$ nezgoda se dogodilo na putu koji se nalazi u podužnom nagibu (pad ili uspon).

\subsubsection{Ukrštanja}

Nekanalisana prostrana ukrštanja puteva i neuređene površine pored kolovoza i u zonama raskrsnica imaju za posledicu dovođenje u zabludu vozača $u$ vezi namene tih površina i potencijalnih konflikata u takvoj zoni. Naime, kada postoji veća površina ukrštanja tada vozači ne mogu pouzdano znati kojom će se putanjom kretati drugi učesnik u saobraćaju, što za posledicu ima mogućnost iznenadne pojave drugog učesnika u saobraćaju. Naime, kako je u pitanju duži front ukrštanja to nije moguće prepoznati jedno mesto na kome može doći do pojave drugog učesnika, već se on može pojaviti na više mesta ili se može pojaviti više učesnika $u$ isto vreme na više mesta, što vozač ne može uvek da isprati i blagovremeno reaguje na svaku od tih promena. Ovo može za posledicu imati neblagovremeno uočavanje učesnika u saobraćaju i kašnjenje u reagovanju a što je posledica načina uređenja i namene površina oko kolovoza. U posmatranom uzorku 32\% nezgoda se dogodilo na raskrsnicama, pri čemu se najveći broj nezgoda dogodio na trokrakoj „T“ rasksnici (14\%).

\subsubsection{Stanje kolovoznog zastora}

U pojedinim saobraćajnim situacijama i stanje kolovoza može biti u uzročnoj vezi sa nastankom soabraćajne nezgode, ali ovaj uticaj je dominantnije zastupljen kao prateći uticaj ili uticaj na težinu posledica. Naime, u slučajevima udara vozila u udarnu rupu na kolovozu, koja ga zbog svojih karakteristika destabilizuje i zbog toga nastane saobraćajna nezgoda, možemo govoriti o uzročnoj povezanosti. Takođe, zaprljanost kolovoza različitim materijalima, vodom, ledom, u pojedinim okolnostima može biti u uzročnoj vezi sa nastankom saobraćajne nezgode, ali samo ako je to opravdano iznenadila učesnike u soabraćaju, pa nisu imali tehničkih mogućnosti da se prilagode tako nastaloj situaciji (18\% nezgoda se dogodilo na mokrom kolovozu). Nije za zanemariti ni ovo kao mogući uzrok saobraćajnih nezgoda, ali je značajno manje prisutan u odnosu na ostale, jer vozači najčešće 
imaju mogućnost da blagovremeno uoče ovakve promene ili pak iz drugih opravdanih razloga očekuju. Naravno i ovde ima izuzetaka, jer vozači nisu dužni da očekuju nebezbedne uslove vožnje, posebno ako oni nisu adekvatno signalisani, a vozači blagovremeno upozoreni na takvu opasnost.

\subsection{Uticaj faktora put na posledice saobraćajne nezgode}

Način planiranja i gradnje puta, kao i stanje kolovoza i površina pored kolovoza najčešće imaju uticaja na posledice saobraćajne nezgode. Kako je osnovni cilj saobraćaja ispunjenje potreba za prevozom stvari i lica sa jednog mesta na drugo u što je moguće kraćem vremenskom periodu, to je neophodno imati u vidu da u takvim uslovima postoji mogućnost greške učesnika u soabraćaju ili otkaza nekog od sistema. Imajući to u vidu put kao elementarna i neizostavna jedinica saobraćajnog sistema bi trebalo da u tim situacijama ne utiče dodatno na težinu posledica takve nezgode, a što u praksi često nije slučaj. Na osnovu iskustava sa terena može se zaključiti da prilikom planiranja i gradnje puteva nije u značajnoj meri vođeno računa o ovim činjenicama. Često se u blizini saobraćajnica koje su projektovane za veće intenzitete vozila i veće eksploatacione brzine grade različiti objekti, postavljaju drugi elementi infrastrukture i sl. Ovo za posledicu ima značajno uvećanje posledica saobraćajnih nezgoda, jer vozila koja učestvuju u nezgodi najčešće udaraju $u$ te objekte gotovo nesmanjenim brzinama, zbog njihove blizine, i trpe značajne posledice.

\subsubsection{Objekti pored puta}

Kada je reč o uticaju puta na uvećanje posledica saobraćajnih nezgoda svakako dominantan uticaj imaju objekti u neposrednoj blizini površina kolovoza, koji najčešće učestvuju u saobraćajnim nezgodama. Kada je reč o ovim objektima, najčešće se među njima izdvajaju stabla drveća (drvoredi) pored puta, zatim stubovi javne rasvete, stubovi za prenos električne energije, odbojne ograde, propusti za vodu pored puta, pristupni putevi preko kanala i sl. Zajednička karakteristika svih ovih objekata je da za izuzetno kratko vreme, gotovo trenutno zauastavljaju vozila, što za posledicu ima značajnu trenutnu promenu brzine, a koja uzrokuje teške povrede. Ovakva specifičnost objekata pored puta ima dirketan uticaj na posledice nezgode jer da nisu takve karakteristike ovih obejkata učesnici nezgode bi mogli biti postepeno usporavani na koji način ne bi trpeli teške posledice.

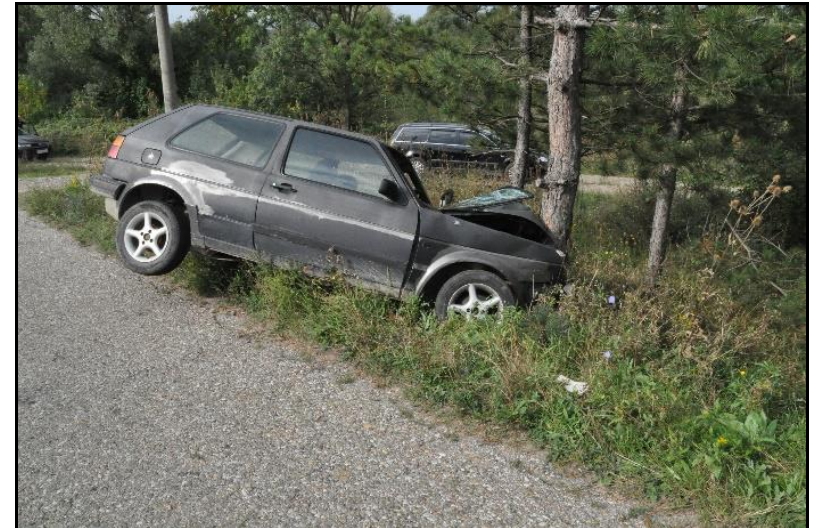

Slika 1. Silazak vozila sa kolovoza i udar u drvo Izvor: Baza podataka o dubinskim analizama SN

Često se pored puta, posebno na pravcima, a koji se nalaze neposredno između krivina, nalaze drvoredi ili pojedinačna stabla drveća, koja najčešće nemaju uticaja na preglednost i na aktivnu bezbednost saobraćaja jer ne utiču na mogućnost nastanka saobraćajne nezgode. $\mathrm{Na}$ taj način gledano ovakva stabla nemaju uticaja na bezbednost saobraćaja, $s$ druge strane smanjuju udare vetrova, imaju uticaja na stabilnost površina pored kolovoza i omogućuju smanjene temperatura što bi se sve moglo podvesti pod prednosti postojanja ovakvih objekata pored puta. S druge strane ovi objekti su izuzetno pasivno nebezbedni jer su izuzetno čvrsti i onemogućavaju elastične sudare što uzrokuje nastajanju teških posledica prilikom urada u ove objekte. Na ovaj način gledano nije poželjno postojanje ovakvih objekata pored puta. Imajući u vidu prednosti i nedostatke postojanja ovakvih objekata jasno je da oni moraju postojati ali in je neophodno kvalitetno zaštiti i omogućiti izbegavanje udara u ovakve fiksne obejkte, postavljanjem drugih objekata zaštite, a koji omogućavaju da se kinetička energija vozila troši u dužem vremenskom intervalu što bi omogućilo manje posledice.

Stubovi javne rasvete su svakako neizostavni deo saobraćajnog mobilijara posebno u naseljima i mestima sa povećanim prisustvom ranjivih učesnika u saobraćaju, jer je neophodno da ta mesta budu dobro osvetljena, kako bi bilo moguće blagovremeno uočavanje svih učesnika u saobraćaju. Kao takvi su od izuzetnog značaja za aktivnu bezbednost jer omogućavaju bolju vidljivost na mestima gde su postavljeni. S druge strane ovi objekti ne mogu biti znatno udaljeni od kolovoza jer tada ne bi omogućili dobru vidljivost, što ograničava mogućnost uklanjanja i pomeranja ovih objekata dalje od kolovoza. Imajući u vidu ove činjenice neophodno je da stubovi javne rasvete i stubovi za prenos električne energije budu napravljeni kao pasivno bezbedni i da omogućavaju male trenutne promene kinetičke energije u cilju smanjenja posledica saobraćajnih nezgoda. 


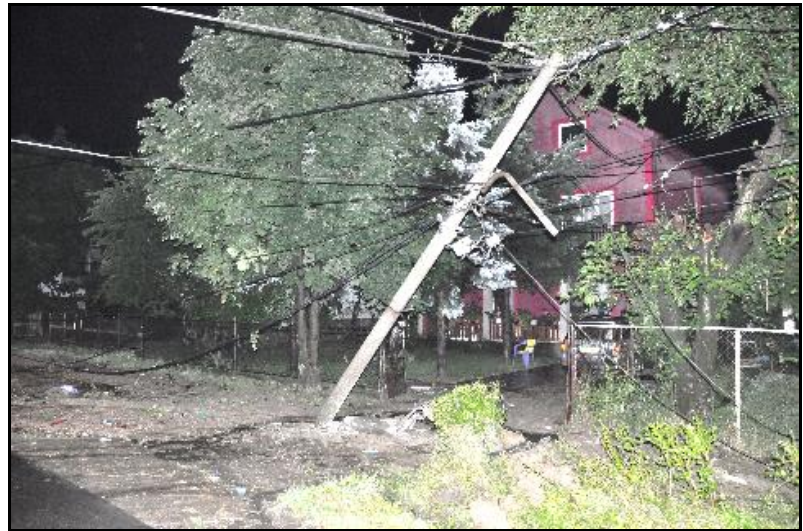

Slika 2. Pasivno nebezbedan betonski stub Izvor: Baza podataka o dubinskim analizama SN

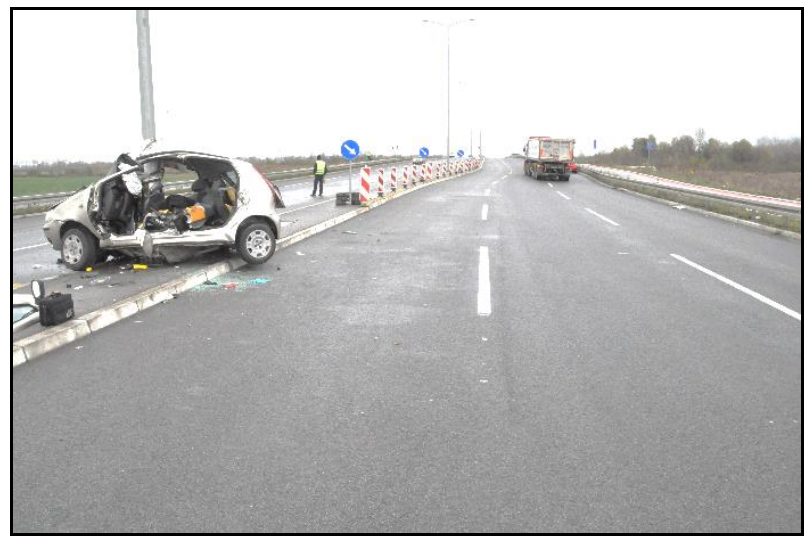

Slika 3. Udar vozila u stub i posledice

Izvor: Baza podataka o dubinskim analizama SN

$\mathrm{Na}$ osnovu sprovedenih analiza, kao posebno nebezbedan objekat na putu, a čija je osnovna namena povećanje bezbednosti, su se izdvojile metalne odbojne ograde. Naime, osnovna uloga odbojnih ograda jeste da zadrže vozila na kolovoznoj površini i onemoguće sletanje vozila sa puta i nastanak većih posledica. Međutim, način izvođenja metalnih odbojnih ograda, a posebno početaka i završetaka često ima uticaja na povećanje posledica nastalih saobraćajnih nezgoda. Naime, često vozila koja izgube upravljivost udaraju u metalnu odbojnu ogradu, pa često i u delove početka odnosno završetka, a koji su u ravni ograde. $\mathrm{Na}$ ovaj način odbojna ograda prodire u vozilo i povećava posledice takvih saobraćajnih nezgoda. Imajući u vidu osnovnu namenu ovih objekata neophodno je obezbediti da ovi elementi budu izvođeni kao pasivno bezbedni i da im počeci budu povijeni od kolovoza i spušteni (ukopani u zemljište), tako da je onemogućen direktan udar vozila u ogradu, kao i da je omogućeno usmeravanje i vraćanje vozila u zonu ograde na kolovozu.

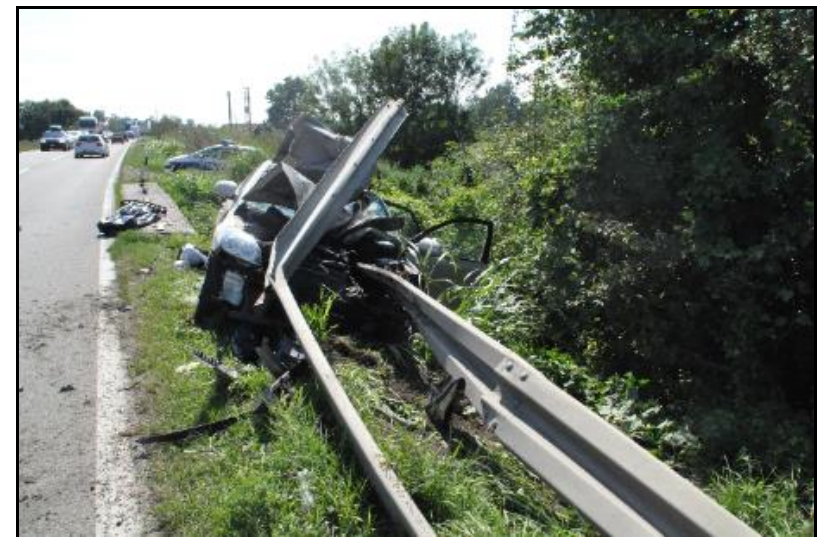

Slika 4. Pasivno nebezbedan početak zaštitne ograde Izvor: Baza podataka o dubinskim analizama SN

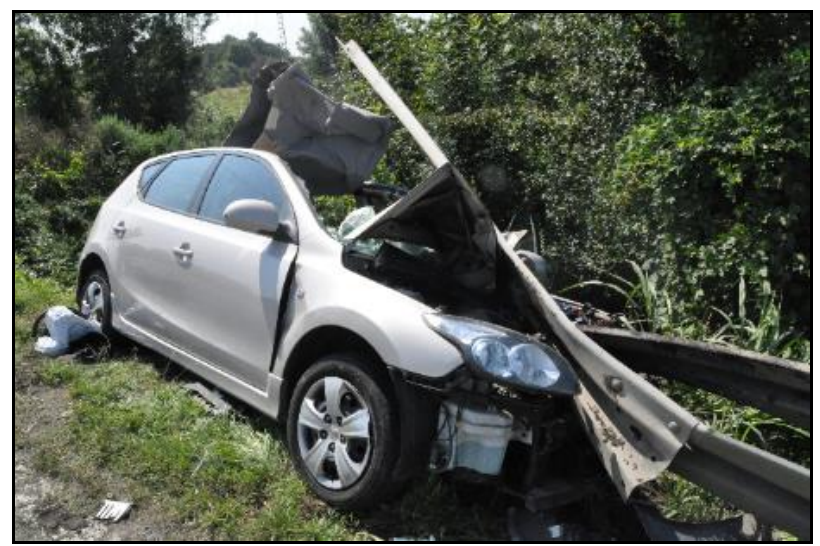

Slika 5. Udar vozila u zaštitnu ogradu i posledice nastale saobraćajne nezgode

Izvor: Baza podataka o dubinskim analizama SN

Propusti za vodu pored puta i pristupni putevi preko kanala su takođe izuzetno pasivno nebezbedni jer kao i prethodni elementi ne omogućavaju nastavljanje kretanja vozila sa delimičnim smanjenjem kinetičke energije, već obezbeđuju gotovo trenutno zaustavljanje vozila, što značajno uvećava posledice nastalih nezgoda.

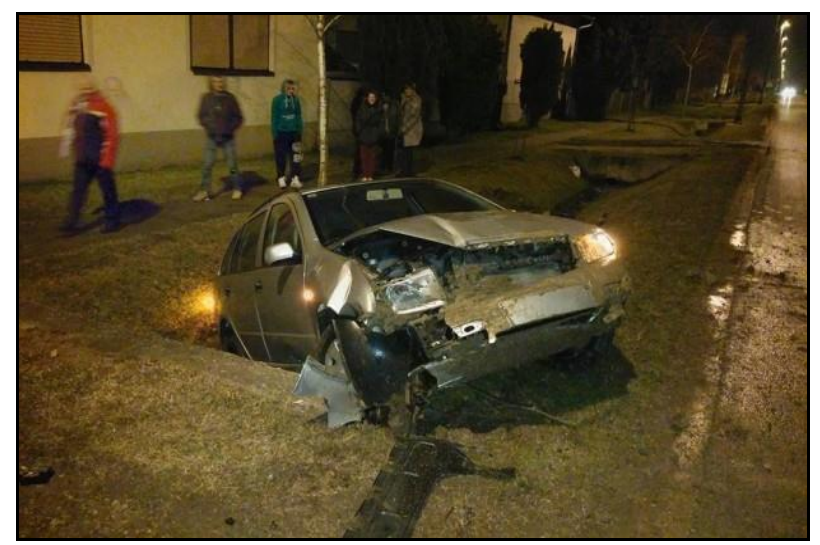

Slika 6. Udar vozila u betonski propust i posledice nastale saobraćajne nezgode

Izvor: Baza podataka o dubinskim analizama SN 
Putni objekti kao što su nadvožnjaci, propusti i slično takođe značajno mogu uticati na težinu posledica saobraćajne nezgode, jer kao i prethodno opisani objekti gotovo trenutno zadržavaju vozila učesnike nezgode.

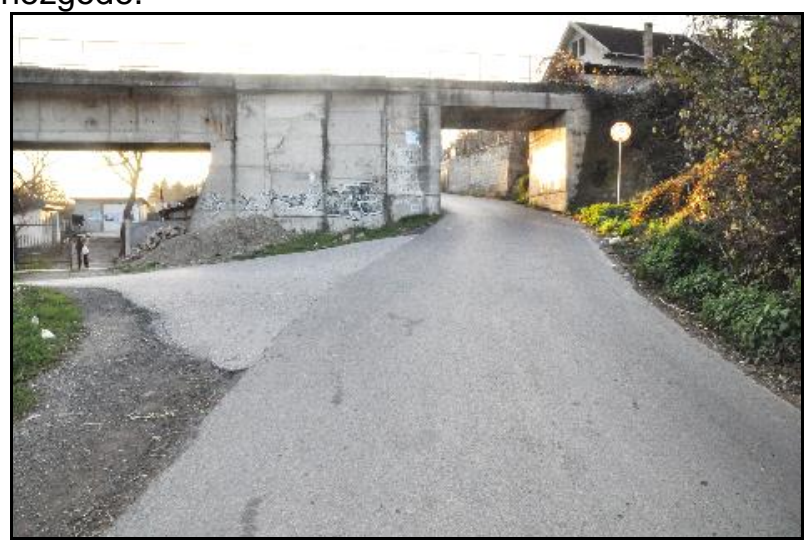

Slika 7. Pasivno nebezbedan nadvožnjak Izvor: Baza podataka o dubinskim analizama SN

\subsubsection{Kosine pored puta i bankine}

Kosine pored puta, odnosno nagibi kosina $u$ zavisnosti kako su izvedeni mogu u pojedinim slučajevima gotovo trenutno zaustaviti vozilo. Kod puteva u nasipu, kanali koji se izvode sa jedne ili obe strane puta, se često zbog konfiguracije terena izvode kao izuzetno duboki, dok s druge strane zbog male širine putnog pojasa se ne izvode u većoj širini, što za posledicu ima postojanje kanala velike dubine sa strmim kosinama. Ovakve strane kanala prilikom silaska vozila sa puta u kanal, ne omogućavaju dalji nastavak kretanja vozila, već ga gotovo trenutno zaustavljaju na tom mestu i na taj način povećavaju posledice saobraćajne nezgode. Zaustavljanje vozila na ovakav način značajno povećava posledice, a što bi bilo izbegnuto ukoliko bi bilo omogućeno dalje usmeravanje vozila duž kanala ili prelazak vozila preko kanala, posebno kada se iza kanala nalaze zemljane površine bez objekata. Ovo se može postići smanjivanjem dubine kanala ili proširivanjem kanala, na koji način bi se smanjili nagibi strana kanala, a što bi omogućavalo lakši prelazak vozila ili pak preusmeravanje vozila duž kanala.

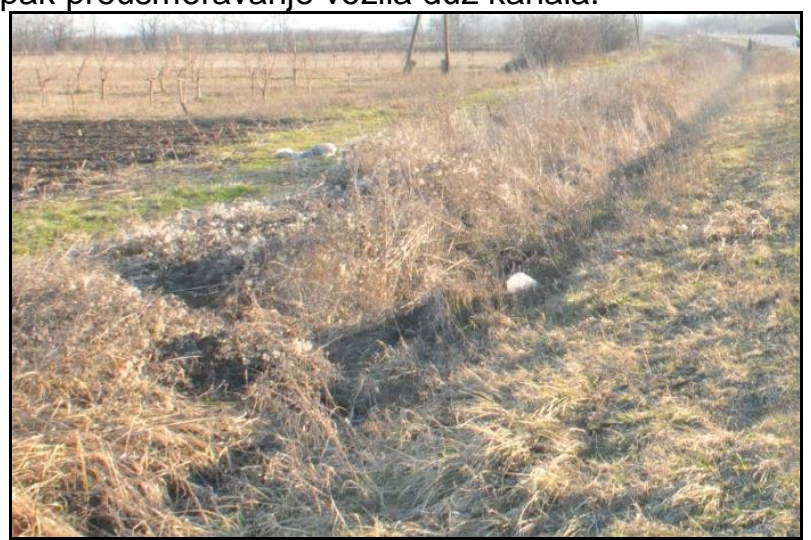

Slika 8. Pasivno nebezbedan odvodni kanal Izvor: Baza podataka o dubinskim analizama SN
Kod puteva u zaseku osim problema kanala, često se javlja i problem nagiba kosine, koja je često izuzetno strma i ne omogućava blago preusmeravanje vozila, već izaziva rotaciju vozila, prilikom udara vozila u kosinu, što za posledicu može imati vraćanje vozila na saobraćajnu površinu i nastanak sekundarne saobraćajne nezgode. Slični problemi se javljaju i kod puteva u useku, jer kosine useka osim uticaja na posledice često imaju uticaja i na nastanak sekundarnih nezgoda.

\section{ZAKLJUČAK}

Dubinske analize saobraćajnih nezgoda, kao što je i prikazano u ovom radu, mogu u velikoj meri pomoći $u$ determinisanju uticaja pojedinih faktora, osnovnih faktora Čovek-Vozilo-Put-Okruženje na nastanak i posledice saobraćajnih nezgoda. $\mathrm{Ni}$ jedna od do sada primenjivanih metoda analiza saobraćajnih nezgoda, zbog svoje specifičnosti rada ili ograničenosti raspoloživih podataka, nema mogućnost da sveobuhvatno analizira svaku pojedinačnu saobraćajnu nezgodu, kao što to rade dubinske analize. Dubinske analize na specifičan način posmatraju svaki od faktora i analiziraju mogući uticaj na konkretnu saobraćajnu nezgodu. Takođe, zbog multidisciplinarnosti radnog tima koji vrši dubinske analize je moguće kvalitetnije sagledavanje potencijalnih uticaja na nastanak i posledice saobraćajne nezgode, a što omogućava adekvatno prepoznavanje stvarnih uticaja u konkretnoj nezgodi.

Uticaj faktora put, kao jedinog faktora koji je permanentno prisutan na konkretnoj lokaciji, je veoma važno analizirati dubinskim analizama jer samo se na taj način mogu stvarno sagledati njegovi uticajni na nastanak i posledice saobraćajnih nezgoda. Kao što je prikazano u ovom radu, na konkretnim primerima, uticaj faktora put nije uvek jasno prepoznatljiv i u potpunosti jasan, a što zahteva sprovođenje ovakvih analiza, kako bi se u potpunosti utvrdio njegov uticaj i u skladu sa prepoznatim uticajem preduzele adekvatne mere. Vršenje dubinskih analiza sa posebnim osvrtom na analizu uticaja faktora put je značajno, ne samo za utvrđivanje uticajnih faktora na nastanak saobraćajnih nezgoda na nekom području, već je značajno i za preduzimanje mera na otklanjanju uočenih nedostataka puta na konkretnom mestu.

Kao što je već prikazano i navedeno u ovom radu, značaj sprovođenja dubinskih analiza saobraćajnih nezgoda je posebno značajno za upravljače puta, jer na pouzdan način mogu dobiti podatke o stvarnom uticaju puta kojim upravljaju na bezbednost saobraćaja. Na ovaj način mogu prepoznati opasne deonice ili mesta na kojima je neophodno preduzeti određene aktivnosti kako bi se povećao nivo bezbednosti saobraćaja i izbeglo stvaranje opasnih 
situacija i saobraćajnih nezgoda. Za upravljače puta sprovođenje dubinskih analiza može imati dvojaki značaj, prvo na konkretnom mestu gde se događaju saobraćajne nezgode analizira se uticaj puta, što za posledicu ima jasne pokazatelje upravljaču šta mora preduzeti na konkretnoj lokaciji. $S$ druge strane značaj sprovođenja dubinskih analiza za upravljača puta je taj što prikupljanjem podataka o uticajima faktora put na nastanak nezgode ima mogućnost da prepozna druga potencijalno opasna mesta, na kojima se još uvek nisu dogodile saobraćajne nezgode, a koja karakteriše postojanje prepoznatih uticajnih faktora nastanka saobraćajnih nezgoda i posledica. To im omogućava preventivno delovanje kako bi se smanjili prepoznati uticaji faktora put $i$ preventivnim delovanjem izbeglo stvaranje potencijalno opasnih mesta i saobraćajnih nezgoda.

Prikupljanje i sistematizacija uticajnih faktora posebno ima značaja za promenu i unapređenje prakse projektovanja, planiranja i izgradnje, jer unapred ukazuje na moguće potencijalno opasne lokacije u saobraćaju, što omogućava blagovremenu izmenu i izbegavanje stvaranja opasnosti u saobraćaju.

\section{Literatura}

[1] Antic, B., Vujanic, M., Lipovac, K., Pesic, D. (2012). Estimation of the traffic accidents costs in Serbia by using dominant costs model. Transport. 26:4, 433-440.

[2] Baldock M., Kloeden C., McLean A. (2008). In-depth research into rural road crashes. Centre for Automotive Safety Research, 116.

[3] Bjorkman, K., Fagerlind, H., Ljung-Aust, M., Lijegren, E. (2008). In-depth accident causation databases and analysis report. Deliverable 5.8 of the EU FP6 project SafetyNet, TREN-04-FP6TR-SI2.395465/506723.

[4] Department for Transport - Great Britain. (2013). Valuation of road accidents and casualties in Great Britain, Annual report.

[5] European Commission. (2010). Towards a European road safety area: Policy orientations on road safety 2011-2020.

[6] European Road Safety Observatory, Project of SafetyNet, 2008. Deliverable 5.8: In-depth accident causation database and analysis report.

[7] Fildes B., Logan D., Fitzharris M., Scully J., Burton D. (2003). The Australian national crash in-depth study 2000-2003. Monash university accident research centre report documentation page 119.

[8] Gitelman, V., Balasha D., Carmel, R., C., Hendel L., Pesahov F. (2012). Characterization of pedestrian accidents and an examination of infrastructure measures to improve pedestrian safety in Israel, Accident Analysis and Prevention, 44, 63-73.

[9] Hill, J., Cuerden, R. (2015). Development and Implementation of the UK On The Spot Accident Data Collection Study Phase I. Department for Transport: London. Road Safety Research Report No. 59.

[10] Марковић, Н., Пешић, Д., Мацура, Д., Селмић, М. (2015). Независне оцене саобраћајних незгода са погинулим на јавним путевима, 10. Међународна Конференција "Безбедност саобраћаја у локалној заједници", Србија, Крагујевац, Хотел Крагујевац, 22 - 25. април 2015.

[11] Marković, N., Pesić, D., Selmić, M., Macura, D. (2015). Značaj vršenja dubinskih analiza saobraćajnih nezgoda za pravilno utvrđivanje uticaja puta na nastanak saobraćajne nezgode, XIV Simpozijum "Veštačenje saobraćajnih nezgoda i prevare u osiguranju".

[12] Odenheimer, G.L., Beaudet, M., Jette, A.M., Albert, M.S., Grande, L., Minaker, K.L. (1994). Performance-based driving evaluation of the elderly driver: safety, reliability and validity. Jouranl of Gerontology: Medical Sciences. 49, 153-159.

[13] Penumaka, P.A., Savino, G., Baldanzini, N., Pierini, M. (2014). In-depth investigation of PTW-car accidents caused by human errors. Safety Sci. 68, 212-221.

[14] Pesic, D., Vujanic, M., Lipovac, K., Antic, B. (2014). In-depth analises of road accidents, state-ofthe-art and the possibilities for the implementation in the Republic of Serbia, Road Accidents prevention 2014, XII International Symposium.

[15] PIARC- Permanent International Association of Road Congresses, 2011. Road Safety Manual.

[16] Reed, S., Morris, A. (2008). Glossary of Data Variables for Fatal and Accident causation databases. Deliverable 5.5 of the EU FP6 project SafetyNet, TREN-04FP6TRSI2. $395465 / 506723$.

[17] World Health Organization. (2013). Global status report on road safety: time for action: 2013. 